\title{
IMPLEMENTATION OF THEMATIC LEARNING IN THE SD N 6 PANJER KEBUMEN
}

\section{Septy Dewi Purwanti, Eka Setya Septiningrum, Akbar Maulana Hidayat, Ratna Hidayah}

Universitas Sebelas Maret septydewi497@gmail.com

\section{Article History}

accepted 30/09/2018

approved 12/10/2018

published 30/10/2018

\section{Keywords}

Thematic Learning, 2013

Curriculum, SDN 6 Panjer

\begin{abstract}
Thematic learning integrates competencies from subjects into themes, which are related to the experience and environment of students. The government requires the transfer of curriculum from KTSP to the 2013 curriculum in the hope of perfecting and overcoming weaknesses in the learning patterns in the previous curriculum. Thematic learning has been implemented in the Kebumen area, one of which is SD N 6 Panjer which has implemented thematic learning in grade I, II, IV, and V. This research want to describe the implementation of thematic learning in SD Negeri 6 Panjer. This research includes qualitative research. Data collection techniques using observation at SD N 6 Panjer. The results showed that the implementation of thematic learning in SD N 6 Panjer in grades $I, I I, I V$, and $V$ was not fully in accordance with the six thematic learning characteristics: 1) student-centered, 2) direct experinces, 3) the separation of subjects was not so clearly, 4) presents the concept of various contents, 5) is flexible, 6) uses the principle of learning while playing.
\end{abstract}

Social, Humanities, and Education Studies (SHEs): Conference Series https://jurnal.uns.ac.id/shes
p-ISSN 2620-9284 e-ISSN 2620-9292 


\section{PENDAHULUAN}

Dunia pendidikan saat ini digemparkan dengan adanya perubahan kurikulum 2006 menjadi kurikulum 2013. Berdasarkan Permendikbud Republik Indonesia Nomor 160 Tahun 2014 tentang Pemberlakuan Kurikulum Tahun 2006 dan Kurikulum 2013 Pasal 5 yang menyebutkan bahwa "Satuan pendidikan dasar dan pendidikan menengah dapat melaksanakan Kurikulum Tahun 2006 paling lama sampai dengan tahun pelajaran 2019/2020". Hal ini menandakan bahwa mulai pada tahun pelajaran 2020/2021, semua jenjang pendidikan harus memberlakukan Kurikulum 2013.

Dalam kurikulum 2013 terdapat pola pembelajaran tematik. Pola pembelajaran ini berbeda dengan pola pembelajaran pada kurikulum 2006 yang berbasis satuan mata pelajaran. Oleh sebab itu, pemerintah menganjurkan semua jenjang pendidikan mulai dari SD, SMP, SMA harus menerapkan pembelajaran tematik dalam setiap pembelajaran yang akan dilaluinya. Hal tersebut mengharuskan guru sebagai garda terdepan dalam pendidikan untuk mengubah pola pembelajarannya dari pembelajaran berbasis mata pelajaran ke pembelajaran tematik terpadu.

Menurut Akbar, dkk (2016: 17) pembelajaran tematik adalah pendekatan pembelajaran yang mengintregasikan berbagai kompetensi dari berbagai mata pelajaran ke dalam tema dengan proses pembelajaran yang bermakna disesuaikan dengan perkembangan siswa. Menurut Majid, A (2014: 80) pembelajaran tematik merupakan salah satu model pembelajaran terpadu (integrated instruction) merupakan suatu sistem pembelajaran yang memungkinkan siswa, baik secara individu maupun kelompok aktif menggali dan menemukan konsep serta prinsip-prinsip keilmuan secara holistik, bermakna, dan otentik. Pembelajaran tematik merupakan suatu pendekatan dalam pembelajaran yang secara sengaja mengaitkan beberapa aspek baik dalam intra mata pelajaran maupun antar mata pelajaran. Dengan adanya pemaduan itu peserta didik akan memperoleh pengetahuan dan ketrampilan secara utuh sehingga pembelajaran menjadi bermakna bagi peserta didik.

Karakteristik pembelajaran tematik berdasarkan materi sosialisasi Kurikulum 2013 dari Kemendikbud (Akbar, dkk, 2016:19), antara lain:

1) Berpusat pada siswa

Siswa berperan sebagai subyek belajar yang utama sedangkan guru berperan memberikan motivasi kepada siswa supaya semangat belajar (motivator) dan memfasilitasi proses pembelajaran dengan melayani, menangani, dan mengarahkan proses pembelajaran (fasilitator).

2) Memberikan pengalaman langsung (direct experiences)

Siswa dihadapkan pada masalah nyata (konkret) secara langsung terjadi di sekitar siswa sebagai bahan untuk mendalami hal-hal yang lebih abstrak.

3) Pemisahan mata pelajaran tidak begitu jelas

Fokus pembelajaran diarahkan pada pembahasan tema-tema yang dikaitkan dengan kehidupan siswa dan hal-hal di sekitar siswa dan pemetaan mata pelajaran terpisah secara tidak begitu jelas.

4) Menyajikan konsep dari berbagai muatan

Menyajikan berbagai konsep dari beberapa mata pelajaran ke dalam suatu proses pembelajaran berdasarkan dengan tema yang ada dan tujuannya untuk membentuk pengetahuan siswa secara holistik tentang konsep yang dipelajari.

5) Bersifat fleksibel

Pembelajaran tematik bersifat luwes yaitu antara satu mata pelajaran dengan mata pelajaran yang lainnya saling dikaitkan berdasarkan kesesuaian isi serta mengaitkan dengan kehidupan keseharian siswa.

6) Menggunakan prinsip belajar sambil bermain dan menyenangkan

Pembelajaran tematik dilaksanakan dengan metode yang menyenangkan dan membuat siswa aktif dalam proses pembelajaran. Metode yang digunakan guru 
hendaknya bervariasi dengan menggunakan metode permainan, drama, demonstrasi, eksperimen dan lain sebagainya.

Thematic Approach is a way of teaching and learning, whereby many areas of the curriculum are connected together and integrated within a theme. It allows learning to be more natural and less fragmented than the way where a school day is time divided into different subject areas whereby children practice exercises frequently related to nothing other than what the teacher thinks up, as he or she writes them on the chalk board. It allows literacy to grow progressively, with vocabulary linked and with spelling and sentence writing being frequently, yet smoothly, reinforced. Asokhan, V. (2014:1) Artinya mata pelajaran yang terintregasi ke dalam sebuah tema memungkinan pembelajaran menjadi lebih alami dengan perkembangan bahasa yang tumbuh secara progresif dengan perbendaharaan kata dengan ejaan dan kalimat yang sering namun lancar dan diperkuat.

Dikutip dari tribunnews.com, di tengah pro dan kontra terkait implementasi Kurikulum 2013 (pembelajaran tematik), pemerintah tentu punya harapan besar untuk mewujudkan sistem pendidikan yang lebih baik. Sebagaimana sering dikemukakan Mendikbud Prof.Dr.Ir. Muhammad Nuh dalam berbagai kesempatan, bahwa Kurikulum 2013 telah dirancang sedemikian rupa agar siswa mampu meraih kompetensi utama, yakni sikap, pengetahuan, dan ketrampilan (afektif, kognitif, dan psikomotor). Kompetensi tersebut diharapkan dapat menggambarkan kualitas yang seimbang antara pencapaian hard skills dan soft skills. Untuk mencapai hal tersebut, pemerintah memandang perubahan kurikulum dari KTSP ke kurikulum 2013 (tematik) merupakan ikhtiar bersama dalam peningkatan mutu pendidikan Indonesia.

Salah satu Sekolah Dasar yang sudah mulai menerapkan pembelajaran tematik dalam kurikulumnya yaitu SD Negeri 6 Panjer yang terletak di Kelurahan Panjer, Kecamatan Kebumen, Kabupaten Kebumen. Pelaksanaan pembelajaran tematik baru diterapkan di kelas I, II, IV, dan V. Kelas I dan IV sudah mulai menerapkan pembelajaran tematik sejak Tahun Ajaran 2017/2018, sedangkan pada kelas II dan V baru menerapkan pembelajaran tematik pada tahun 2018/2019. Sehingga pembelajaran tematik yang dipayungi oleh Kurikulum 2013 ini masih tergolong kurikulum yang baru bagi guru sebagai fasilitatornya, maupun bagi siswa yang menjadi subjeknya.

Penelitian yang pernah dilakukan oleh Childa Irene (2013:117) yang berjudul "Implementasi Pembelajaran Tematik pada Siswa Kelas Rendah di SD N Balekerto Kecamatan Kaliangkrir" menyatakan bahwa pada tahap perencanaan, pelaksanaan, maupun penilaian masih belum sepenuhnya menggunakan pembelajaran tematik karena dalam penyampaian materi masih terpisah-pisah. Menurutnya hambatan pembelajaran tematik adalah kurangnya sosialisasi mengenai pembelajaran tematik serta keterbatasan alat peraga membuat pembelajaran tematik di SD tersebut kurang maksimal. Merujuk pada penelitian terdahulu yang telah berhasil menemukan implementasi pembelajaran tematik di kelas rendah, mendorong ketertarikan peneliti untuk menyelidiki Implementasi Pembelajaran Tematik di SD N 6 Panjer Tahun Ajaran: 2018/2019.

\section{METODE}

Jenis penelitian yang dilakukan peneliti yaitu penelitian kualitatif. Teknik pengumpulan data merupakan cara yang digunakan peneliti untuk mendapatkan data dalam suatu penelitian. Teknik pengumpulan data yang digunakan pada penelitian ini yaitu observasi. Alat pengumpulan data yang digunakan dalam penelitian adalah catatan lapangan, dan lembar observasi. Subjek penelitian ini adalah SD Negeri 6 Panjer. Dalam penelitian ini, sesuai dengan objek penelitian maka peneliti memilih observasi terstruktur. Observasi ini dilakukan dengan mengamati secara langsung proses pembelajaran tematik di kelas I, II, IV, dan V. Observasi dilakukan mulai dari tanggal 4 - 8 September 2018. 


\section{HASIL DAN PEMBAHASAN}

Penelitian ini dilakukan untuk mengetahui tentang penerapan pembelajaran tematik yang ada di Sekolah Dasar Negeri 6 Panjer. Berdasarkan hasil observasi mengenai pembelajaran tematik di kelas I,II,IV,V di SD N 6 Panjer maka ditemukan data yang disesuaikan dengan karakteristik pembelajaran tematik menurut materi sosialisasi Kurikulum 2013 dari Kemendikbud (Akbar, dkk, 2016:19) sebagai berikut.

Tabel 1. Hasil Observasi Pembelajaran Tematik di SDN 6 Panjer

\begin{tabular}{|c|c|c|c|c|c|}
\hline Karakteristik & $\mathbf{I}$ & II & IV & V & Skor \\
\hline Berpusat pada siswa & - & - & $\checkmark$ & $\checkmark$ & $50 \%$ \\
\hline Direct experiences & - & $\checkmark$ & $\checkmark$ & $\checkmark$ & $75 \%$ \\
\hline Pemisahan mata pelajaran tidak begitu jelas & - & - & - & $\checkmark$ & $50 \%$ \\
\hline Menyajikan konsep dari berbagai muatan & $\checkmark$ & $\checkmark$ & - & - & $50 \%$ \\
\hline Bersifat fleksibel & $\checkmark$ & - & - & - & $25 \%$ \\
\hline Prinsip belajar sambil bermain & - & $\checkmark$ & $\checkmark$ & - & $50 \%$ \\
\hline \multirow[t]{2}{*}{ Persentase } & & & & & 45,75 \\
\hline & $33 \%$ & $50 \%$ & $50 \%$ & $50 \%$ & $\begin{array}{c}\% / 50 \\
\%\end{array}$ \\
\hline
\end{tabular}

Berdasarkan hasil observasi di atas, maka dapat dibuat tabel hasil observasi pembelajaran tematik di SD N 6 Panjer

1) Indikator berpusat pada siswa berdasarkan observasi menunjukkan presentase data sebesar $50 \%$. Artinya indikator berpusat pada siswa dalam pelaksanaan pembelajaran tematik di SD N 6 Panjer sudah 50\% terlaksana yaitu di kelas IV dan V. Hal ini ditunjukkan dengan adanya penugasan praktik membuat layang-layang secara berkelompok di kelas IV. Hal yang sama ditunjukkan di kelas V saat siswa diminta oleh guru untuk berdiskusi pada pembelajaran PPKn dan penilaian bermain pianika dengan lagu "Ibu Kita Kartini". Berdasarkan analisis peneliti, berpusat pada siswa lebih efektif diterapkan pada kelas tinggi, karena anak sudah mulai bisa berdiskusi dan menemukan sendiri tentang materi yang dipelajari dengan baik. Hal ini sesuai dengan pendapat Antika (2014:253) yang menyatakan dalam pembelajaran berpusat pada siswa, guru harus berperan sebagai pengajar, motivator, fasilitator, dan innovator. Guru berperan membantu murid untuk memecahkan masalah saat murid mengalami kesulitan dalam proses pembelajaran.

2) Direct experiences sudah terlaksana pada kelas II, IV, V, artinya $75 \%$ sudah terlaksana pembelajaran yang memberikan pengalaman secara langsung terhadap siswa. Pada kelas II siswa mengalami langsung dalam penggunaan media benda padat, cair, dan gas di lingkungan sekitar. Pada kelas IV anak-anak mengalami langsung untuk membuat layang-layang. Serta pada kelas $\mathrm{V}$ siswa mencari sendiri ide pokok serta hak, kewajiban, dan tanggung jawab sebagai anggota keluarga, serta melalui pengalaman memainkan pianika dengan lagu "Ibu Kita Kartini". Hal ini sejalan dengan pendapat Padmono (2012:14) yang menyatakan dalam pembelajaran tematik murid memiliki kesempatan berinteraksi langsung dengan bahan kajian pengetahuan serta konsep konsep. Infomasi yang diperoleh berdasarkan fakta yang dilihat dan dialami langsung (otentik).

3) Indikator pemisahan mata pelajaran tidak begitu jelas baru terlaksana $25 \%$ yaitu hanya pada kelas $\mathrm{V}$ karena guru kelas $\mathrm{V}$ dapat melakukan pemindahan mapel yang satu ke yang lain dengan halus. Sedangkan pada kelas lain belum muncul karena antara mata pelajaran yang satu dengan yang lain masih jelas perpindahannya. Hal ini jelas berbanding terbalik dengan teori yang diungkapkan 
Hernawan (2015:3) menyatakan bahwa fokus pembelajaran diarahkan pada pembahasan tema-tema yang dikaitkan dengan kehidupan siswa dan hal-hal di sekitar siswa dan pemetaan mata pelajaran terpisah secara tidak begitu jelas.

4) Indikator menyajikan konsep dari berbagai muatan muncul pada kelas I dan II dengan kata lain sudah muncul $50 \%$. Hal ini terlihat saat pembelajaran di kelas I ada penggabungan muatan dari materi SBdP tentang alat musik tradisional dan materi Bahasa Indonesia tentang menulis dan membaca. Penekanan materi membaca, menulis, dan menghitung (calistung) memang masih diutamakan saat pembelajaran kelas I karena hal itu merupakan konsep utama belajar. Sedangkan pada pembelajaran kelas II terlihat sudah muncul konsep IPA tentang wujud benda,Matematika tentang perkalian, serta SBdP tentang gerak dasar tari. Konsep dari berbagai muatan tersebut sudah mulai terlihat pada pembelajaran sesuai dengan tuntunan yang terdapat pada buku guru dan siswa. Disesuaikan dengan pendapat Murfiah (2017:8) yang menyatakan bahwa pembelajaran terpadu dikemas dengan tema atau topik tentang suatu wacara yang dibahas dari berbagai disiplin keilmuan dari berbagai aspek bidang kajian sehingga penggunaan waktu untuk pembahasannya lebih efisien dan pencapaian tujuan pembelajaran lebih efektif.

5) Indikator bersifat fleksibel menunjukkan presentase $25 \%$, itu artinya masih satu kelas yaitu kelas I, yaitu ditandai dengan adanya kaitan antar mapel yang dimuat dalam 1 tema. Jelas masih berbanding terbalik dengan pendapat Ahmadi dan Amri (2014:85) teori bersifat fleksibel atau luwes yaitu antara satu mata pelajaran dengan mata pelajaran yang lainnya saling dikaitkan berdasarkan kesesuaian isi serta mengaitkan dengan kehidupan keseharian siswa. Objek yang menjadi pembelajaran tematik menekankan pada fenomena alam, social, seni dan budaya. Melalui pendekatan itu diharapkan peserta didik mempunyai kompetensi sikap, keterampilan dan sikap jauh lebih baik siswa diharapkan lebih kreatif, inovatif dan produktif sehingga dapat mengatasi persoalan dan tantangan pada masa depan.

6) Prinsip belajar sambil bermain sudah menunjukkan $50 \%$, itu berarti dua kelas II dan IV sudah memasukkan sebuat permainan ke dalam pembelajarannya. Kelas II bermain benda-benda yang berwujud cair,padat, dan gas. Pada kelas IV justru langsung praktik membuat mainan layang-layang. Jadilah anak yang kreatif untuk membuat maianannya sendiri. Pembelajaran dilaksanakan dengan metode yang menyenangkan dan membuat siswa aktif dalam proses pembelajaran. Metode yang digunakan guru hendaknya bervariasi dengan menggunakan metode permainan, drama, demonstrasi, eksperimen dan lain sebagainya. Melalui berbagai macam metode, siswa dapat mengenal aturan, bersosialiasi, toleransi, kerjsama, sportif, dan sikap-sikap positif lainnya (Rachmawati, 2011:42)

Sedangkan uraian pembelajaran tematik di setiap kelas berdasarkan data hasil observasi dan wawancara yang disesuaikan dengan karakteristik pembelajaran tematik menurut materi sosialisasi Kurikulum 2013 dari Kemendikbud (Akbar, dkk, 2016:19)

1) Pada pembelajaran yang terlaksana di kelas I baru menunjukkan indikator menyajikan konsep dari berbagai muatan dan bersifat fleksibel. Materi yang diajarkan yaitu muatan Bahasa Indonesia tentang menulis dan membaca serta muatan SBdP tentang macam-macam alat musik tradisional dan bunyinya. Sedangkan indikator yang lain belum muncul karena pada pembelajaran yang dilakukan, guru menyampaikan materi pelajaran hanya menggunakan metode ceramah, tanya jawab, dan penugasan. Guru hanya menggunakan buku siswa dan papan tulis sebagai alat pembelajaran, dan tidak menggunakan media atau alat peraga tentang materi alat musik tradisional. Keadaan siswa kelas I di SDN 6 Panjer masih belum lancar membaca dan menulis, suka bermain-main, belum dapat menyimpulkan materi yang dipelajari, dan siswa lebih banyak berbicara dengan teman di sebelahnya. Keadaan siswa kelas I tersebut sesuai dengan teori 
Piaget tentang perkembangan kognitif individu fase preoperational stage dimana anak usia 2-7 tahun lebih mudah belajar menggunakan benda yang konkret daripada menggunakan kata-kata atau anak pada usia tersebut belum dapat berpikir abstrak (Jauhar,2011:13). Namun dalam pembelajaran di kelas I, guru memfokuskan pembelajaran dengan metode ceramah dan memberi tugas supaya siswa dapat belajar menyimak, membaca dan menulis dengan baik.

2) Pada proses pembelajaran yang terlaksana di kelas II sudah menunjukkan indikator direct experiences, menyajikan konsep dari berbagai muatan, dan prinsip belajar sambil bermain. Hal ini dapat diketahui dari hasil observasi pembelajaran tematik di kelas II yang menunjukkan bahwa guru menggunakan metode ceramah, pengamatan, demonstrasi dan tanya jawab dalam menyampaikan materi. Guru sudah menyajikan konsep dari berbagai materi tentang wujud benda, perkalian, dan gerak dasar tari namun pemisahan mata pelajaran tersebut sangat jelas. Selain itu, guru melaksanakan pembelajaran sambil bermain dengan cara menyediakan media benda konkrit seperti kecap, air dalam botol, kantong plastik, spidol, air sirup, dan balon untuk materi sifat-sifat wujud benda serta praktik tentang gerak dasar tari. Secara umum, siswa memperhatikan guru saat pembelajaran karena siswa tertarik dengan media yang dibawa oleh guru. Pembelajaran tematik dengan menggunakan media di kelas II tersebut sesuai dengan teori yang dijelaskan oleh Millah dan Syah (2017:255) bahwa siswa kelas rendah lebih mudah memahami hal-hal yang bersifat konkret daripada yang abstrak dan bermain merupakan sesuatu yang dibutuhkan dan dianggap serius. Namun, dari berbagai metode yang digunakan, guru lebih menekankan pada metode ceramah supaya semua materi dapat tersampaikan dengan tepat waktu karena siswa belum dapat membedakan secara jelas perbedaan bermain dengan bekerja.

3) Observasi pembelajaran tematik di kelas IV sudah menunjukkan indikator berpusat pada siswa, direct experience, dan prinsip belajar sambil bermain. Hal ini ditunjukkan pada saat pembelajaran terdapat pembagian kelompok, setiap kelompok diberi tugas untuk membawa alat dan bahan untuk membuat layanglayang. Siswa diminta kerja sama dalam membuat layang layang dengan melihat langkah kerja membuat layang-layang pada buku siswa. Kegiatan berkelompok tersebut mempunyai manfaat yang sesuai dengan salah satu ciri-ciri umum strategi pembelajaran tematik yang dijelaskan oleh Hartono (2014:158) yaitu mengasah dan mengembangkan potensi sosial anaknya layaknya toleransi, kerja sama, dan tanggap terhadap berbagai perbedaan yang dimiliki oleh orang lain. Di sisi lain, indikator pemisahan mata pelajaran tidak begitu jelas, penyajian konsep dari berbagai muatan, dan bersifat fleksibel belum terlihat. Hal ini dikarenakan pembelajaran pada saat itu belum kondusif karena waktu yang singkat dan siswa terfokus pada tugas yang diberikan guru saat itu.

4) Pada proses pembelajaran di kelas $V$ telah menunjukkan indikator berpusat pada siswa, direct experiences, dan pemisahan mata pelajaran tidak jelas. Hal ini diketahui dengan hasil observasi yang menunjukkan bahwa pada awal kegiatan pembelajaran, guru bersama siswa membahas pekerjaan rumah tentang contoh hak, kewajiban, dan tanggung jawab dari anggota keluarga. Selanjutnya, guru meminta siswa untuk membaca sebuah cerita yang terdapat di buku siswa kemudian siswa diminta untuk berdiskusi mencari informasi dari isi cerita tersebut. Perpindahan mata pelajaran satu ke mata pelajaran yang lain terlihat tidak jelas karena guru dapat melakukan perpindahan antar mata pelajaran dengan halus. Selain itu, dalam pembelajaran belum menunjukkan penyajian konsep dari berbagai muatan karena pada saat observasi seharusnya terdapat pembelajaran tentang Bahasa Indonesia dan IPA, namun saat itu hanya tersampaikan mata pelajaran Bahasa Indonesia. Hal ini terjadi karena kuantitas materi dalam satu mata pelajaran cukup banyak sedangkan siswa masih lama dalam mempelajari 
materi sehingga guru mengambil langkah untuk lebih mengedepankan pemahaman siswa terhadap suatu mata pelajaran sampai siswa benar-benar paham tentang materi yang dipelajari. Rentang usia kelas $\mathrm{V}$ yang sudah mencapai (9-12 tahun) dan sudah terglong kelas tinggi memang sudah sesuai jika dikondikan pembelajaran seperti yang telah diuraikan. Hal ini sejalan dengan pendaat Sobur (2011:132) yang menyatakan usia 9-11 tahun siswa dianggap sebagai usia matang untuk belajar dan sudah mencapai tingkat objektivitas yang tinggi.

Hasil penelitian yang telah peneliti lakukan menunjukkan bahwa ada keselarasan dengan hasil penelitian Childa Irene (2013:117) yang menyatakan bahwa pada tahap perencanaan, pelaksanaan, maupun penilaian masih belum sepenuhnya menggunakan pembelajaran tematik karena dalam penyampaian materi masih terpisah-pisah. Hal ini selaras dengan hasil penelitian yang telah dilakukan peneliti bahwa implementasi pembelajaran tematik belum terlaksana secara maksimal sesuai dengan indikator pembelajaran tematik karena presentase rata-rata dari hasil observasi yang dikaitkan dengan karakteristik pembelajaran tematik masih menunjukkan angka 45,75\% sampai dengan 50\%, dengan rincian berpusat pada siswa $(50 \%)$, direct experiences (75\%), pemisahan mata elajaran tidak begitu jelas (50\%), menyajikan konsep dari berbagai muatan (25\%), bersifat fleksibel (25\%), prinsip belajar sambil bermain (50\%). Sedangkan presentase munculnya karakteristik pembelajaran tematik tiap kelasnya yaitu: Kelas I (33\%), Kelas II (50\%), Kelas IV (50\%), dan Kelas V (50\%).

\section{SIMPULAN}

Berdasarkan hasil dan pembahasan yang telah diuraikan di atas, maka dapat disimpulkan bahwa implementasi pembelajaran tematik di SD N 6 Panjer pada kelas I, II, IV, dan V belum sepenuhnya sesuai dengan enam karakteristik pmbelajaran tematik yaitu: 1) berpusat pada siswa, 2) direct experinces, 3) pemisahan mata pelajaran tidak begitu jelas, 4) menyajikan konsep dari berbagai muatan, 5) bersifat fleksibel, 6) menggunakan prinsip belajar sambil bermain. Dengan rincian presentase rata-rata dari hasil observasi yang dikaitkan dengan karakteristik pembelajaran tematik masih menunjukkan angka $45,75 \%$ sampai dengan $50 \%$, atau dapat dikatakan belum maksimal.

\section{DAFTAR PUSTAKA}

Ahmadi, I. K. dan Amri, S. (2014). Pengembangan dan Model Pembelajaran Tematik Integratif. Jakarta : Prestasi Pustaka.

Akbar, Sa'dun, dkk. (2016). Implementasi Pembelajaran Tematik di Sekolah Dasar. Bandung: PT. Remaja Rosdakarya.

Antika, R. R. (2014). Proses Pembelajaran Berbasis Student Centered Learning (Studi Deskriptif di Sekolah Menengah Pertama Islam Baitul 'Izzah, Nganjuk). BioKultur, 3(1), 251-263.

Asokhan, V. (2014). Thematic Approach for effective communication in ECCE. Int $J$ of Education and Psychological Research (IJEPR), 3(3), 49-51.

Hartono, Rudi. (2014). Ragam Model Mengajar Yang Mudah Diterima Murid. Jogjakarta: Diva Press

Hernawan, A. H. (2015). Pengembangan Model Pembelajaran Tematik di Kelas Awal Sekolah Dasar. .Bandung : UPI Press.

Irene, C. (2013). Implementasi Pembelajaran Tematik Pada Siswa Kelas Rendah di SD Negeri Balekerto Kecamatan Kaliangkrik. Yogyakarta: Universitas Negeri Yogyakarta.

Jauhar. (2011). Implementasi Paikem dari Beharioristik Sampai Konstruktivistik. Jakarta: Prestasi Pustakarya 
Majid, Abdul. (2014). Pembelajaran Tematik Terpadu. Bandung: PT. Remaja Rosdakarya.

Millah dan Syah. (2017). Implementasi Pembelajaran Tematik Integratif di Kelas I Sekolah Dasar Negeri 2 Barongan Kudus. 5 (3). 251-276.

Murfiah. (2017). Pembelejaran Terpadu Teori dan Praktik Terbaik di Sekolah. Bandung : Refika Aditama.

Padmono. (2012). Pembelajaran Terpadu untuk Guru SD. Surakarta: Yuma Pustaka.

Rachmawati. (2011). Strategi Pengembangan Kreativitas Pada Anak. Jakarta: Kencana Prenada Media Group.

Rokhman, F. (2014, Desember 3). Harapan Besar Implementasi Kurikulum 2013. Tribunnews Online.Diakses dari: http://www.tribunnews.com/

Sobur, A. (2011). Psikologi Umum. Bandung: Pustaka Setia. 